\title{
マルコフ過程振幅正弦波による脳波頭皮上 分布モデル
}

$\begin{array}{lllll}\text { 正員西田茂人 } & \text { (佐賀大) } \\ \text { 正員 中 村 政 俊 (任嘪大) } \\ \text { 非会員柴 崎 } & & \text { 浩 (佐賀医科大) }\end{array}$

\section{1. まえがき}

脳波とは，大脳皮犋の多数の神経細胞におけるシナ プス後電位の総和を頭皮上から記録したものであり， 脳波の判読は頭皮上の複数の部位加ら導出された脳波 の時間および空間分布に基ついてなされている(1)。

脳波の空間分布を定量的に表現する力法として，複 数の部位から導出した脳波そのものに補間法を邀用し て脳波の頭皮上分布を表現する方法(2)や，8～13 Hz の $\alpha$ 波成分を多く含む脳波の各時刻に叔りる頭皮上 分布を定量的に表すことによって $\alpha$ 波の時間的空間 的変化を表現する方法(3)などがある。また，外部から の感覚刺激に対する中枢神経系の反応である誘発電位 関して屯、スプライン関数老用いた頭皮上分布表現 がなされている(4)。これらの表現方法は，いずれ屯脳 波や誘発電位の電位そのものに，補間法などを適用し て頭皮上分布表現をする方法であり，数学的なモデル を用いた方法ではない。脳波に関する数式モデルとし て，AR モデルや ARMA モデル(5)(6)があるが，てれ らは1つの部位の特徵を表す脳波モデルであって頭皮 上分布は表現していない。また，それらの脳波モデル は, 脳波の定量化の立場からは有用であるか，医学的 立場加らた脳波特徴之の対応が直感的にとりにくい 難点を有する。

本諭文では，臨床における脳波判読において最む基 本となる背景脳波（頭皮上に掠いて全般的汃持続的

\footnotetext{
EEG Model for Scalp Topography by Markov Amplitude Sinusoidal Waves. By Shigeto Nishida, Member, Masatoshi Nakamura, Member (Faculty of Science and Engineering, Saga University) \& Hiroshi Shibasaki, Non-member (Department of Internal Medicine, Saga Medical School).

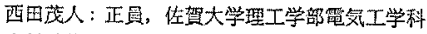

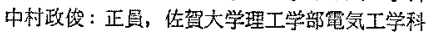

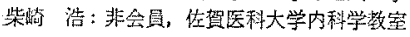

な波の連続）の頭皮上分布在定量的に表現する脸波頭 皮上分布モデルを提案する。このモデルの構造は，覌 皮上脳波の各部位間の位相情報が付加された一次マル コフ過程振幅正弦波が数㧽重疊したものである。との 脳波モデルは，脳波時系列之統計的性質を合致させる ことを目指していて, 各时刻の脳波そのものの一致を 狙うものではない。徒って，モデルのパラメー夕は， モデルの理論パワースペクトルと脳波のパワースペク トルの誤差 2 乘和の最小化によって決定する。重畳波 の各成分のパラメータは，脳波の周波数化関して分類 さ机ている(1) $\delta$ 波 $(0.5 \sim 4 \mathrm{~Hz}), \alpha$ 波 $(8 \sim 13 \mathrm{~Hz}), \beta$ 波 ( $13 \mathrm{~Hz}$ 以上) それぞれの波の平均周波数, 振幅, 遷移係数および各部位間の位相差に対応している。従 って本モデルは，脳波判読医による脳波判読結果と直 感的対応がとりやすいという特長があり，単一部位に 対するモデルパラメータと脳波判読医による㨫波判読 結果との対忘に関しては，すでに良い結果を得てい $3^{(7)}$ 。実際に，正常被㭘者の頭皮上 5 䈉所の部位加ら 導出した睬波に対する頭皮上分布モデルを構成したと ころ，モデル出力時系列の波形の統計的性澌が脑波の 性質とよく一致していて，脳波特徽の頭皮上分布蛙毛 デルパラメータの值によって定量的に表現できた。

なお，モデル時系列のサンプル間隔上，モデルパラ メータの值之の間の重要な関係式を導いた。この関牦 式を用いることにより，粗いサンプル間隔 $10 \mathrm{msec} の$ 脳波データを基にして決定したもデルパラメータ加ら 細かいサンプル間隔 $1 \mathrm{msec}$ のデルの時系列を発生 させることができた。

本論文では，第 2 章で脳波モデルの構造，第 3 章で モデルパラメータの決定法を示し，第 4 章で正常被梌 者の脳波頭皮上分布モデルの構成を行い，サンプル間 隔とモデルパラメータの関係の証明は付録で行った。 


\section{2. 脳波頭皮上分布モデルの構造}

提案する脳波䫑皮上分有モデルは，基本部位の脳波 モデル $x^{1}(n \Delta t)$ 之複数個の派生部位の脳波モデル $x^{2}$ $(n \Delta t)$ とからなり, 各部位の脳波モデルは一次マルコ フ過程の振湢を有する正弦波が $K$ 個重䑁した形で表 される。

基本部位 1 に対する脳波モデルの構造は

$$
x^{1}(n \Delta t)=\sum_{k=1}^{K} a_{k}{ }^{1}(n \Delta t) \sin \left(2 \pi m_{k} n \Delta t-\theta_{k}{ }^{1}\right)
$$

$$
a_{k}^{1}((n+1) \Delta t)=\gamma_{k}^{1} a_{k}^{1}(n \Delta t)+\xi_{k}(n \Delta t)
$$

で表され，これは先に提案したマルコフ過程振幅正弦 波モデル(7)に位相情報 $\theta_{k}{ }^{1}$ を付加したあのである。こ こで, $m_{\mathrm{s}}$ は平均周波数, マルコフ過程振幅 $a_{k}^{1}(n \Delta t)$ 中の $r_{k}{ }^{1}$ は遷移係数， $\xi_{k}(n \Delta t)$ は平均值が 0 で分散加

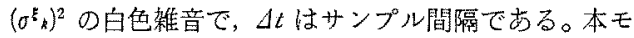
デルは，わずか $2 ， 3$ 個の正弦波の重畳からなる少な い個数のパラメータによって脳波の特徽を正確に表現 することができる。また，各波は，脳波の周波数に関 して分類されている $\delta$ 波， $\alpha$ 波， $\beta$ 波に，それぞれ対 応させるととがでさるので，本モデル中のパラメー 夕は，脳波判衤医による脳波判定結果との直感的対応 がとりやすいという特長を有する(7)。たとえば， $m_{*}$ は各波の平均周波数に対応し， $T_{k}$ は各波の持続の程度 を表している。

派生部位 2 亿対する脸波モデルは，

$$
x^{2}(n \Delta t)=\sum_{k=1}^{K} a_{k}{ }^{2}(n \Delta t) \sin \left(2 \pi m_{k} n \Delta t-\theta_{k}{ }^{2}\right)
$$

$$
a_{k}^{2}((n+1) \Delta t)=\gamma_{k}^{2} a_{k}^{2}(n \Delta t)+b_{k} \xi_{k}(n \Delta t)
$$

で表され，これは基準部位 1 のデルと比較すると， 正弦波の個数 $K$ 上平均周波数 $m_{k}$ および白色雑音 $\xi_{k}$ $(n \Delta t)$ の值は等しく，マルコフ過程の大力ゲイン $b_{k}$, 潖移係数 $\gamma_{k}^{2}$ と位相 $\theta_{k}^{2}$ の值が異なっている。

脳波頭皮上分布モデルをブロック图で示すと图10 ようになる。畄波の発生源として周波数の罢なる $K$ 個の正弦波 $\sin \left(2 \pi m_{k} n \Delta t\right)$ 之独立な白色㩲音 $\xi_{k}(n \Delta t)$ の対を想定し，それらの信号が各伝搬経路を伝わると きにそれぞれの部位によってマルコフ過程の入力ゲイ ン $b_{k}$ ，遷移係数 $r_{k}^{2}$ 亡位相 $\theta_{k}^{2}$ が異なると仅定してい る。すなわち，翼なった部位から導出した脳波は，同 一の発生源加発生した波に，部位特有の伝般特性の

\section{器生源 \\ 伝洀経 路}

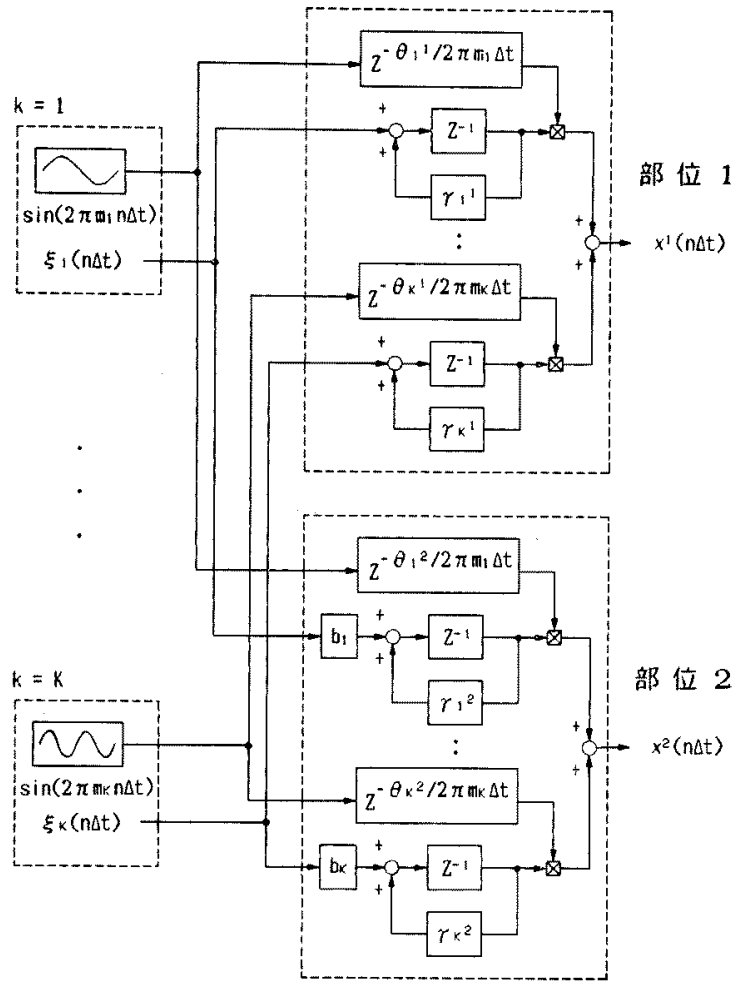

图 1 脳波頭皮上分布モデルのブロック图

Fig. 1. Block diagram of the EEG (electroencephalogram) model for scalp topography.

变换を施すことによって表現することができる。この モデルにおいて，基準部位 1 の位相 $\theta_{k}^{1}$ と派生部位 2 の位相 $\theta_{\mathrm{k}}{ }^{2}$ それぞれの值住意味をむたず全く自由に選 んでよいが，その両者の美である位相差

$$
\theta_{k}=\theta_{k}{ }^{2}-\theta_{k}{ }^{1},(k=1, \cdots, K)
$$

は頭皮上の脳波の伝般の遅れ老す重要なパラメータ である。

また，その他の派生部位 3 以降に関してあ派生部位 2 とモデル構造は同じであり，伝搬部分のパラメータ の値が買なるだけである。

\section{3. モデルパラメータの決定法}

提穼した脳波モデルは，脳波時系列と統計的性質を 合致させるこしを目指していて，各時咕の波形そのむ のの一致を狙うあのではない。说って，モデルパラ メータは, パワースペクトルとクロススペクトルをむ とに決定する。その为定法には、スペクトル最谪分布 関数近以法 ${ }^{(8)}$ 採朋する。この方法は脳波パワースペ 
クトルとモデルの理諭パワースペクトルの誤差 2 耕和 を評価閵数として設定し，評㑡関数が曼小となるモデ ルパラメータを極值探索法 (Fletcher-Powell 法(9)) 決定する方法である。脳波僌皮上分布モデルパラメー 夕は，基準部位亡 1 つの派生部位の 2 部位ごとに求め る。求めるべきモデルパラメータを

$$
z=\left[m_{k}, r_{k}^{1}, \sigma_{k}^{k}, \gamma_{k}^{2}, b_{k}, \theta_{k}\right],(k=1, \cdots, K)
$$

なる $6 K$ 個の要素をあつベクトルで衣し，これらの

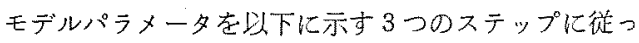
て決定す吕。

\section{ステップ1}

基準部位 1 に対する畄波モデルのパラメータ年決定 する。(1)式の理譣パワースペクトルは

$$
\begin{aligned}
g_{1}(f)= & \sum_{k=1}^{K} \frac{0.25 \Delta t\left(\sigma^{\xi}\right)^{2}}{1+\left(\gamma_{k}^{1}\right)^{2}-2 r_{k}^{1} \cos \left\{2 \pi \Delta t\left(f-m_{k}\right)\right\}} \\
& +\frac{0.25 \Delta t\left(\sigma_{k}\right)^{2}}{1+\left(\gamma_{k}^{1}\right)^{2}-2 \gamma_{k}{ }^{1} \cos \left\{2 \pi \Delta t\left(f+m_{k}\right)\right\}}
\end{aligned}
$$

となる(7)。基䧱部位 1 から㧛出された脳波にFFT を適用して計算したパワースヘククルと（5)式の理諭 パワースペクトルの譟差 2 垂和からなる評洒関数苍設

け，この評価関数を最小纪するようなパラメ一タ

$$
\hat{z}_{1}=\left[\hat{m}_{k}, \hat{\gamma}_{k}^{1}, \sigma_{k}\right], \quad(k=1, \cdots, K) \ldots \ldots(6)
$$

を決定する。

ステップ 2

派生部位 2 に対する脳波モデルのパラメータを決定 する。(2)式の理論パワースペクトルは

$$
\begin{aligned}
g_{2}(f)= & \sum_{k=1}^{K} \frac{0.25 \Delta t\left(b_{k} \sigma_{k}\right)^{2}}{1+\left(\gamma_{k}^{2}\right)^{2}-2 r_{k}^{2} \cos \left\{2 \pi \Delta t\left(f-m_{k}\right)\right\}} \\
& +\frac{0.25 \Delta t\left(b_{k} \sigma_{k}^{\xi}\right)^{2}}{1+\left(\gamma_{k}^{2}\right)^{2}-2 \gamma_{k}^{2} \cos \left\{2 \pi \Delta t\left(f+m_{k}\right)\right\}}
\end{aligned}
$$

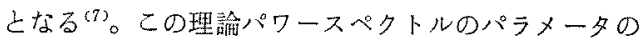
うち周波数と程音分散に関しては，ステップ1の基準 部位で決定した発生源のパラメータの值 $\hat{m}_{k}, \hat{\sigma}^{\xi}{ }_{k}$ を採 用する。民れや外のパラメータ $\gamma_{k}^{2}, b_{k}$ に関しては，

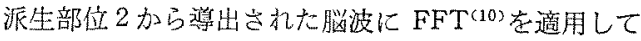
計算したパワースペクトルと， $\hat{m}_{k}, \sigma_{k} \xi$ の值を代入し た（7）式の理諭パワースペクトルの誤差 2 乗和からな る評価関数を設けて，乙の評価関数が最小となるよう なバメータ

$$
\hat{\boldsymbol{z}}_{2}=\left[\hat{\gamma}_{k}^{2}, \hat{b}_{k}\right], \quad(k=1, \cdots, K)
$$

在決定する。

ステップ 3

(3)式で示された基染部位 1 と派生部位 2 におりる
位相差 $\theta_{k}$ の推定值は，2部位間の脳波のクロススペ クトル $Q(f)$ を計算し，そのフェイズの周波数 $\hat{m}_{k} に$ お纱る値莸

$$
\hat{\boldsymbol{z}}_{3}=\left[\hat{\theta}_{k}\right]=\left[\angle Q\left(\hat{m}_{k}\right)\right], \quad(k=1, \cdots, K)
$$

し採用する。

$$
\begin{aligned}
\text { ステップ } 1 \sim 3 \text { で決定したパラメータをまとめて } \\
\dot{\boldsymbol{z}}=\left(\hat{\boldsymbol{z}}_{1}, \hat{\boldsymbol{z}}_{2}, \hat{\boldsymbol{z}}_{3}\right] \\
=\left[\hat{m}_{k}, \hat{\gamma}_{k}{ }^{1}, \hat{\sigma}_{k}{ }_{k}, \hat{\gamma}_{k}{ }^{2}, \hat{b}_{k}, \hat{\theta}_{k}\right], \quad(k=1, \cdots, K)
\end{aligned}
$$

で表し，これを(4)式のモデルパラメータ $z$ の推定値 とする。このようにして求めたモデルパラメータ之 は，サンプル間隔 $\Delta t$ で離散化した脳波データを用い て構成したモデルのパラメータである。

\section{サンプル間隔とモデルパラメータとの関係式}

(4)式のモデルパラメータ学求めるときの临波デー タのサンプル間隔 $\Delta t$ の值と，その決定されたモデル パラメータを用いて (1)，(2)式から発生させるモデ ル時系列のサンプル間隔 $\Delta t^{\prime}$ は必ずしす一致させる必 要はない。一般に比較的粗いサンプル間隔 $\Delta t$ の脳波 データをあとにモデルを構成し，モデルの利用目的に 応じて細かいサンプル開隔 $\Delta t^{\prime}$ でのモデル出力を得た いという事態によく遭遇する。たとえば，モデルパラ メータを決定するときの計算時間を短縮し，モデル出 力は運続的な脳济時系列により近い形で比較したい場 合などである。このように，サンプル間隔が变化した とき，(1)，(2)式の離散時間の脳波モデルが普遍的 な性筫を保持するためには，モデルパラメータにある 変換岩施す必要がある。以下サンプル間隔とモデルパ ラメータの犆この間の重要な関䋆式を導いたその結果 老示。

(1-1)，(2-1) 式中の平均周波数 $m_{k}$ c位相 $\theta_{k}{ }^{1}, \theta_{k}{ }^{2}$ は サンプル間隔が变化しても不変である。サンプル間隔 によって変化するパラメータは，(1-2)，(2-2)式中の $r_{k}^{1}, \gamma_{k}^{2}, \sigma_{k}^{k}, b_{k}$ である。この4つのパラメーダに関す る関係式蓬導くときの基本的考え方は，サンプル間隔 が異なる襍散時間モデルを生み出す元の連続モデルは 同一であるということである。サンプル間隔 $\Delta t$ 就 けるモデルパラメータを $\gamma_{k}^{1}, \gamma_{k}^{2}, \sigma^{k_{k}, b_{k}}$ とし, サンプ

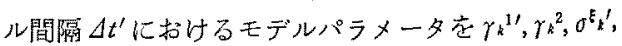
$b^{\prime}{ }^{\prime}$ とすると, 雨者の間の関係は

$$
\begin{aligned}
& \gamma_{k^{\prime}}{ }^{\prime}=\left(\gamma_{k}^{1}\right)^{s t^{\prime} / s t} \\
& \gamma_{k}^{2 \prime}=\left(\gamma_{k}^{2}\right)^{d t^{\prime} / \Delta t} \\
& \left(\sigma^{\xi_{k}}\right)^{2}=\left(\sigma^{\xi_{k}}\right)^{2} \frac{1-\left(\gamma_{k}{ }^{\prime \prime}\right)^{2}}{1-\left(\gamma_{k}\right)^{2}}
\end{aligned}
$$




$$
\left(b_{k}\right)^{2}=\left(b_{k}\right)^{2} \frac{\left\{1-\left(\gamma_{k}\right)^{2}\right\}\left\{11-\left(\gamma_{k}^{2^{\prime}}\right)^{2}\right\}}{\left\{1-\left(\gamma_{k}^{1}\right)^{2}\right\}\left\{1-\left(\gamma_{k}^{2}\right)^{2}\right\}}
$$

となった(付録 I)。

更化，(11)，(12)，(13)，(14)式の関䋆式で結ばれて いる離散時間モデルにおいて，サンプル間隔が変化し ても, モデルの理墖パワースペクトルの面皘は不変で 古ることを証明した（付録II）。

\section{4. 正常被検者の脳波頭皮上分布モデル}

本章では，正常被検者の頭皮上５筒所の部位から導 出した実脳波に対して，第 2 章，筙 3 章で示したす法 で実際に脳波頭皮上分有モジルを構成する。国際䉓策 法 (10-20 system) ${ }^{(1)}$ に上る頭皮上 5 筍所の部位(図 2)

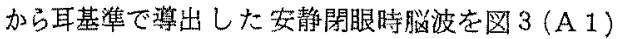

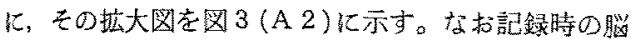
波計の低周波つィルタの時定数は $0.3 \mathrm{sec}$, 高周波遮 断周波数は $500 \mathrm{~Hz}$ でる。この脳波データをサンプ

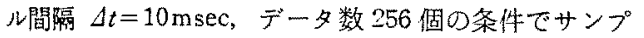

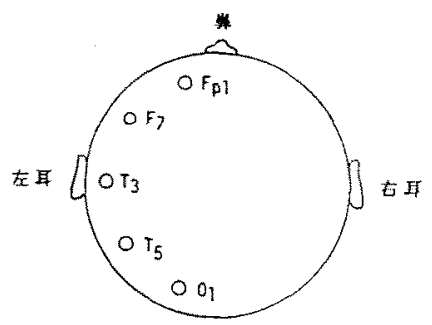

図 2 電極配置 (10-20 泫)

Fig. 2. Electrode placements (ten-twenty system).
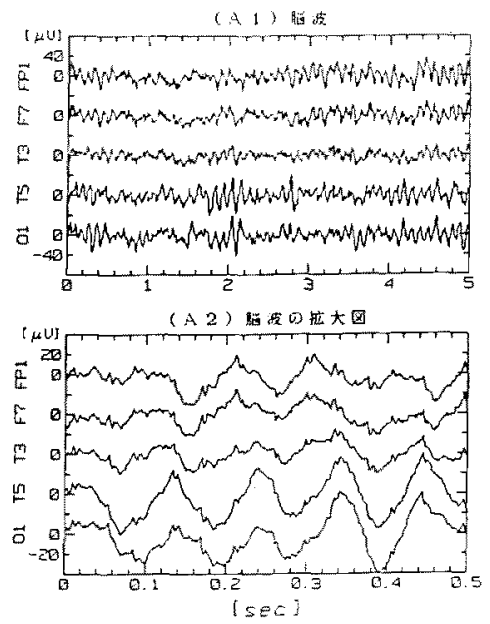

図 3 渴诐とモデル出力

Fig. 3. EEG and model output.
ルし，そ机 FFT ${ }^{(20)}$ によりピリオドグラムを求め, 同様の手順で求めた 10 個のピリオドグラムの平均値 で表されるパワースペクトルを図4亿示す。

圆3(A1)，因4 加占，各部位の脳波结，8１3 $\mathrm{Hz}$ の $\alpha$ 波成分方墁屯多く，0.5 4 Hz の 8 波带域上 13 $\mathrm{Hz}$ 以上の $\beta$ 波带域に少しバワーが存在していること

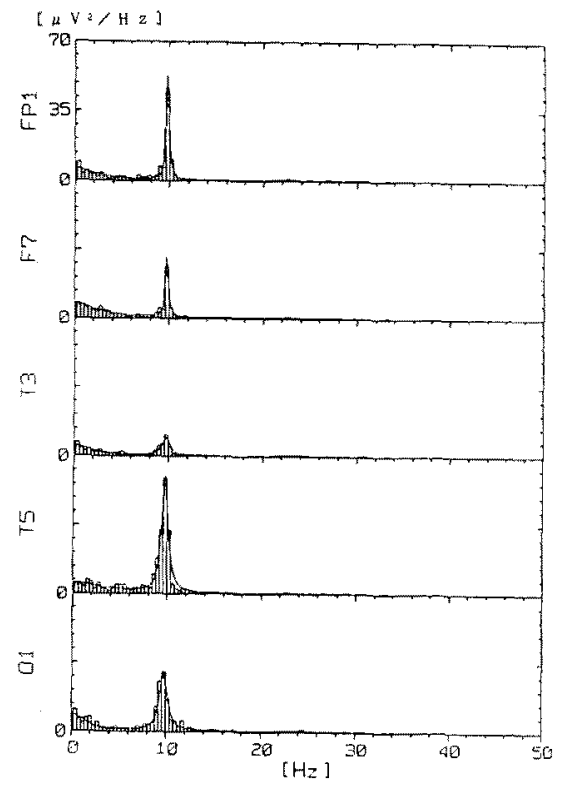

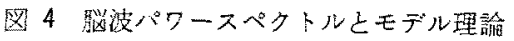
パワースベクトル

Fig. 4. Power spectrum of the EEG and theoretical power spectrum of the model.
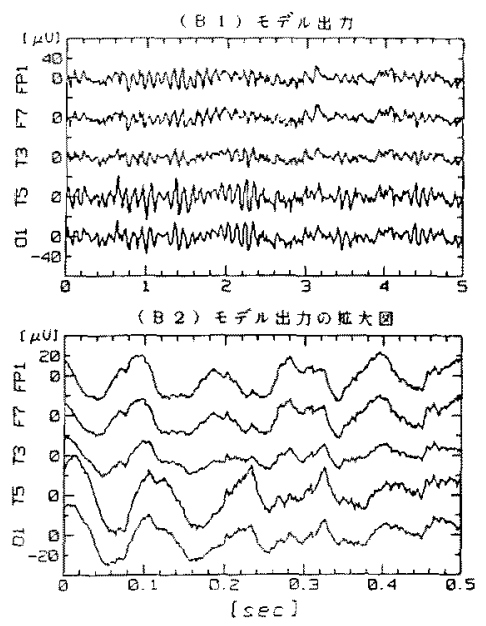
がわかる。 $\alpha$ 波成分の各部位の特徽を調べると，図 4 から，平均周波数はいずれの部位においてもほほ同し であり，そのパワーの大きさと尖度が異なることがわ 加る。また，図 $3(\mathrm{~A} 2$ ) 加ら，部位によって $\alpha$ 波の 位相がずれていることるかかる。これらの特徽は, 脳 波頭皮上分布モデルの笘造を(1)，(2)式の形に決定 するに至った基本となっている。

基䧱部位 1 は任意に選んでよいが，ここでは，臨床 において膎波を判読する際に重視している儤位律趿 (成人では $\alpha$ 波) 加最夺多い後頭部の部位 O.を選心。 そして，その他の部位を派生部位 $2,3,4,5$ しして, 基準部伎と 4 つの派壵部位の脳波モデルのパラメータ は，3章で述心た手順のうちステップ1を1回，ス テップ2，3を 4 回適用して決定した。モデルパラ メータ决定に用いたデータは，サンプル間陶 $\Delta t=10$ msec の時系列から計算した図 4 のパワースペクトル と，基準部位 $O_{1}$ 上その他の派坐部位間の夕ロススペ クトルのフェイズの值である。脳波モデルの一次マル コフ過程振幅正弦波の固数は $K=3$ とし，てれそれ行 波は, $\delta$ 波, $\alpha$ 波， $\beta$ 波に対応させている。

表 1 には，このようにして決定したモデルパラメー 夕の值 $(\Delta t=10 \mathrm{msec})$ と, $(11) \sim(14)$ 式の变換公式に よって計算したモデルパラメータの值 $\left(\Delta t^{\prime}=1 \mathrm{msec}\right)$ 走示す。だし，基染部位 $O_{1}$ に掠ける $b_{k}$ の項には 白色雑音の標準偏差 $\sigma^{k_{k}}$ の值を元している。ここで, $k=1$ は $\delta$ 波, $k=2$ は $\alpha$ 波, $k=3$ は $\beta$ 波に対応して いる。サンプル間隔 $10 \mathrm{msec}$ ごとのモデル出力の時 系列を図 3 (B 1) に，サンプル間隔 $1 \mathrm{msec}$ ごとの特 系列を図 3 (B 2) に，(5)，(7)式を用いて計算した 理諭パワースペクトルの形状を図 4 の実線で示してい る。本モデルでは時系列の各時刻の波形そのすのを䅧 波に一致させるのではなく，時系列全体の統計的性椞 を合わせることを目的としているが，図3(B 1)のモ デル時系列は図 3(A 1) の脳波時系列亡視覚的に統計 的性買がよく一致しているととがわかり，かつ図4よ りモデルの理諭パワースペクトルは脳波パワースペク トルと形状がよく一致していて統計量の値をのものも 非常によく一致していることがわかる。また，図 3 (B 2)のモデル時系列の㹡大図におりる各部位間の位 根差が, 図3(A 2)の実脳波の位相差とよく似加。 ていることがわかる。

\section{5.むすび}

本論女では，脳波の頭皮上分布を定量的に表現する 脳波頭皮上分布モデルを提案しだ。本モデルは，頭皮 上の各部位間の位相差情報をとり入れた一次マルコフ 過程振幅正弦波が数個重盢したあのである。このモデ ルの各波は，脳波の周波数に関して分類さ机ている 波， $\alpha$ 波， $\beta$ 波それぞ机の平均周波数，振幅，倦梨係 数，位相などのパラメータで表すことができるので，

表 1 モデルパラメータ

Table 1. Model parameters.

\begin{tabular}{|c|c|c|c|c|c|c|c|c|c|}
\hline & \multirow[b]{2}{*}{$k$} & \multicolumn{4}{|c|}{$\Delta t=10 \mathrm{msec}$} & \multicolumn{4}{|c|}{$\Delta t^{\prime}=1 \mathrm{msec}$} \\
\hline & & $m_{k}$ & $\gamma_{k}$ & $\begin{array}{c}b_{k} \\
\left(\sigma_{k}\right)\end{array}$ & $\theta_{k}$ & $m_{k}$ & $\gamma_{k}$ & $\begin{array}{c}b_{k} \\
\left(\sigma^{t} k\right)\end{array}$ & $\theta_{k}$ \\
\hline \multirow{3}{*}{$F p q$} & 1 & 0.44 & 0.843 & 1.26 & 0.12 & 0.44 & 0.983 & 1.29 & 0.12 \\
\hline & 2 & 9.75 & 0.989 & 0.48 & -1.57 & 9.75 & 0.999 & 0.48 & -1.57 \\
\hline & 3 & 25,00 & 0.906 & 0.99 & -0.13 & 2500 & 0.990 & 0.99 & -0.13 \\
\hline \multirow{3}{*}{$F_{7}$} & 1 & 0.44 & 0.831 & 1.49 & 0.31 & 0.44 & 0.982 & 1.54 & 0.31 \\
\hline & 2 & 9.75 & 0.989 & 0.36 & -1.50 & 9.75 & 0.999 & 0.36 & -1.50 \\
\hline & 3 & 25.00 & 0.872 & 1.01 & -0.01 & 25.00 & 0.986 & 1.03 & -001 \\
\hline \multirow{3}{*}{$T_{3}$} & 1 & 0.44 & 0.869 & 0.99 & 0.10 & 0.44 & 0.986 & 1.00 & 0.10 \\
\hline & 2 & 9.75 & 0.971 & 0.54 & -0.68 & 9.75 & 0.997 & 0.53 & -0.68 \\
\hline & 3 & 25.00 & 0.881 & 1.05 & 0.12 & 25.00 & 0.987 & 1.05 & 0.12 \\
\hline \multirow{3}{*}{$T_{5}$} & 1 & 0.44 & 0.778 & 1.68 & 0.07 & 0.44 & 0.975 & 1.79 & 0.07 \\
\hline & 2 & 9.75 & 0.976 & 1.08 & 0.35 & 9.75 & 0.998 & 1.07 & 0.35 \\
\hline & 3 & 25.00 & 0.866 & 0.99 & 0.06 & 25.00 & 0.986 & 1.01 & 0.06 \\
\hline \multirow{3}{*}{$O_{1}$} & 1 & 0.44 & 0.897 & $(4.37)$ & - & 0.44 & 0.989 & $(1.45)$ & - \\
\hline & 2 & 9.75 & 0.969 & $(3.44)$ & - & 9.75 & 0.997 & $(1.10)$ & - \\
\hline & 3 & 25.00 & 0.900 & $(1.50)$ & - & 25.00 & 0.990 & $(0.50)$ & - \\
\hline
\end{tabular}


AR モデルや ARMA モデルと比して脳波判読医によ る脳波判㜔結果之直感的対応がとりやすいという点で 優れている。てれらのモデルパラメータは, パワース ペクトルの誤差 2 乘和の最小化婂よって決定した。実 脳波を用いて脳波頭皮上分布モデルを構成した結果， モデルの統計的性質が実脳波の性質とよく一致し，各 部位間の脳波位相差も適切に表現することができた。 また，モデル時采列のサンプル間隔とモデルパラメー タの值との重要な関保式を導くことによって，異なっ た希望のサンプル間隔のモデル時系列を発生させるこ とを可能にした。

(昭和 62 年 12 月 28 日受付)

\section{文朝}

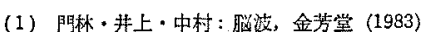

(2) T. Estrin \& R. Uzgalis: "Computer display of spatiotemporal EEG patterns", IEEE Trans. Bio-med. Eng., 16, $192 / 196$ (1969)

(3) D Lehmann: "Multichannel topography of human alpha EEG fields", Electroenceph. clin. Neurophysiol., 31, $439 / 449$ (1971)

(4) F. Perrin, J. Pernier, O. Bertrand, M.H. Giard \& J F. Echallier: "Mapping of scalp potentials by surface spline interpolation", Electroenceph. clin. Neurophysiol., 66, $75 / 81(1987)$

(5) W. Gersch \& J. Yonenoto: "Automatic Classification of EEGs: A Parametric Model New Features for Classification Approach", JACC, 762/769 (1977)

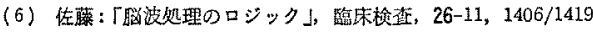
(1982)

（7）西田・中树・柴崎：「マルコフ過程振幅正弦波に上る联波モ デル」，医用露子と生体工学，24-1，8/14 (1986)

（8）西田・中村・柴崎:「脳跛特徽抽出のだめのパワースペクト

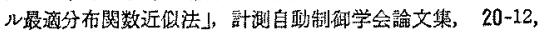
$1150 / 1155$ (1984)

(9) R. Fletcher \& M.J.D. Powell : "A rapidly convergent descent mathod for minimization", The Computer Jour $n a l, 6,163 / 168$ (1963)

(10) 森下 -小烟：僄号処理, 計䘞自秒制御学会 (1982)

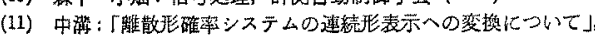
第15回確率システムシンポジウム，4/6 (1983)

\section{付 録}

\section{I．サンプル間隔とパラメータの関係の証明}

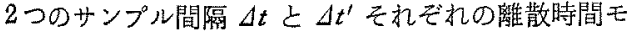
デルの中のパラメータの関倸式を導くにあたって，2 つの離散時間モデルはいずれ向同一の連続時間モデル から生み出されたという考えに基づく。

一次マルコフ過程の連続時闆モデル

$$
\dot{a}_{k}{ }^{1}(t)=p_{k}{ }^{1} a_{k}{ }^{1}(t)+u_{k}(t)
$$

を教える。乙こで， $u_{k}(t)$ は平均值 0 ，分散 $\left(\sigma^{u}{ }^{*}\right)^{2}$ の 白色雑音である。こ机をサンプル間隔 $\Delta t$ で離散化し たとき，離散時間モデルは (1-2)式に示すとおり

$$
a_{k}^{1}((n+1) \Delta t)=\gamma_{k}{ }^{1} a_{k}{ }^{1}(n \Delta t)+\xi_{k}(n \Delta t)
$$

である。ここで， $\gamma_{k}^{1}$ は

$$
\gamma_{k}{ }^{1}=\left.\mathcal{L}^{-1}\left\{1 /\left(S-p_{k}{ }^{1}\right)\right\}\right|_{\iota=\Delta t}=\exp \left(p_{k}^{1} \Delta t\right)
$$

であり, $\xi_{k}(n \Delta t)$ は

$$
\begin{aligned}
\xi_{k}(n \Delta t)= & \int_{n \Delta t}^{(n+1) \Delta t} \exp \left(p_{k}^{1}((n+1) \Delta t-\tau)\right) \\
& \left.\times u_{k}(\tau) d \tau \ldots \ldots \ldots \ldots \ldots \ldots \text { (付 } 4\right)
\end{aligned}
$$

である。こてで， $\xi_{k}(n \Delta t)$ の統計的性質を計算すると， 平均値は

$$
\begin{aligned}
E\left[\xi_{k}(n \Delta t)\right]= & \int_{n \Delta t}^{(n+1) \Delta t} \exp \left(p_{k}^{1}((n+1) \Delta t-\tau)\right) \\
& \times E\left[u_{k}(\tau)\right] d \tau \\
= & 0 \ldots \ldots \ldots \ldots \ldots \ldots \ldots \ldots \text { (付 } 5)
\end{aligned}
$$

分散は

$$
\begin{aligned}
\left(\sigma^{\xi_{k}}\right)^{2} \triangleq & E\left[\xi_{k}(n \Delta t)^{2}\right] \\
= & \int_{n \Delta t}^{(n+1) \Delta t} \int_{n \Delta t}^{(n+1) \Delta t} \exp \left(p_{k}^{1}((n+1) \Delta t-\tau)\right) \\
& \times \exp \left(p_{k}^{1}\left((n+1) \Delta t-\tau^{\prime}\right)\right) E\left[u_{k}(\tau)\right. \\
& \left.\times u_{k}\left(\tau^{\prime}\right)\right] d \tau d \tau^{\prime} \\
= & \left(\sigma^{u}\right)^{2} \int_{n \Delta t}^{(n+1) \Delta t} \exp \left(2 p_{k}{ }^{1}((n+1)\right. \\
& \times \Delta t-\tau)) d \tau \\
= & \left.\left(\sigma^{u}\right)^{2}\left(\left(\gamma^{1}\right)^{2}-1\right) / 2 p_{k}{ }^{1} \ldots \ldots \ldots \text { (付 } 6\right)
\end{aligned}
$$

となる。

一方，(付 1)式の連続時間システムに対して異なっ たサンプル間隔 $\Delta t^{\prime}$ で表した離散時間モデルを

$$
\begin{aligned}
& a_{k}{ }^{\prime \prime}((n+1) \Delta t) \\
& \quad=\gamma_{k}{ }^{1 \prime} a_{k}{ }^{2 \prime}(n \Delta t)+\xi_{k}{ }^{\prime}(n \Delta t)
\end{aligned}
$$

こする。ここで $\gamma^{1{ }^{\prime \prime}}$ の値之 $\xi_{k^{\prime}}(n \Delta t)$ の分散は，(付 $3)$ （付 6 )式上同様保

$$
\begin{aligned}
& \left.\gamma_{k}{ }^{1 \prime}=\exp \left(p_{k}^{1} \Delta t^{\prime}\right) \ldots \ldots \ldots \ldots \ldots \ldots \text { (付 } 8\right) \\
& \left.\left(\sigma_{k}^{F^{\prime}}\right)^{2}=\left(\sigma_{k}^{u}\right)^{2}\left(\left(\gamma_{k}{ }^{1 \prime}\right)^{2}-1\right) / 2 p_{k}{ }^{1} \ldots \ldots \text { (付 } 9\right)
\end{aligned}
$$

である。

両離散時間モデルを生み出す連続モデルは同一であ るので，パラメータ $p_{k}{ }^{1}$ と $\sigma^{4}$ は は其通である。従っ $\tau$ ，(付 3)，(付 6)，(付 8)，(付 9) 式加万 $p^{1}{ }^{1}<\sigma^{*} k$ を消去す机ば，両者のパラメータには，

$$
\begin{aligned}
& \gamma_{k}{ }^{1 \prime}=\left(\gamma_{k}{ }^{1}\right)^{d t^{\prime} / \Delta t} \\
& \left(\sigma^{\xi} k^{\prime}\right)^{2}=\left(\sigma_{k}\right)^{2} \frac{1-\left(\gamma_{k}{ }^{1 \prime}\right)^{2}}{1-\left(\gamma_{k}\right)^{2}}
\end{aligned}
$$

なる関係式が導出される。

(2-2)式に關しても，同㥞の手順で計算すれば，(付 10)，(付11)式の代りに

$$
\gamma_{k}^{2 \prime}=\left(\gamma_{k}^{2}\right)^{d t^{\prime} / \Delta t}
$$




$$
\left(b_{k}^{\prime} \sigma^{\xi_{k}}\right)^{2}=\left(b_{k} \sigma^{\xi_{k}}\right)^{2} \frac{1-\left(\gamma_{k}{ }^{2}\right)^{2}}{1-\left(\gamma_{k}^{2}\right)^{2}}
$$

が得られ，(付13)式に(付11)式を代入する上

$$
\left(b_{k}\right)^{2}=\left(b_{k}\right)^{2} \frac{\left\{1-\left(\gamma_{k}\right)^{2}\right\}\left\{1-\left(\gamma_{k}{ }^{\prime \prime}\right)^{2}\right\}}{\left\{1-\left(\gamma_{k}{ }^{1 \prime}\right)^{2}\right\}\left\{1-\left(\gamma_{k}\right)^{2}\right\}}
$$

となる。

また，(付 1)式の連続時間モデルを(付 2) 式の離散 時間モデルへ離散化した結果は, 離散時間モデルの相 関関数がサンプル時点に扔ける連続時間モデルの相関 関数と一致するように離散化した結果 (11) と一致して いる。

\section{II. パワースペクトルの面積の不変性の証明}

(1)式の脳波モデルの理論パワースペクトルを表す （5）式の面積を計算する。（5)式をナイキスト周波数 $1 / 2 \Delta t$ まで積分すると

$$
\begin{aligned}
S= & \sum_{k=1}^{K} \int_{0}^{1 / 2 \Delta t} \\
& \times\left[\frac{0.25 \Delta t\left(\sigma^{\xi_{k}}\right)^{2}}{1+\left(\gamma_{k}^{1}\right)^{2}-2 \gamma_{k}^{1} \cos \left\{2 \pi \Delta t\left(f-m_{k}\right)\right\}}\right.
\end{aligned}
$$

$$
\begin{gathered}
+\frac{0.25 \Delta t\left(\sigma_{k}^{k}\right)^{2}}{1+\left(\gamma_{k}^{1}\right)^{2}-2 \gamma_{k}^{1} \cos \left\{2 \pi \Delta t\left(f+m_{k}\right)\right\}} d f \\
\left.=\sum_{k=1}^{K} 0.25\left(\sigma^{k}\right)^{2} /\left(-1\left(\gamma_{k}^{1}\right)^{2}\right) \ldots \ldots \ldots \text { (付 } 15\right)
\end{gathered}
$$

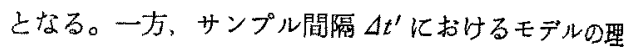
論パワースペクトル6同様にして計算すると

$$
S^{\prime}=\sum_{k=1}^{K} 0.25\left(\sigma^{\xi} k^{\prime}\right)^{2} /\left(1-\left(\gamma_{k^{2}}\right)^{2}\right) \ldots
$$

となる。（付16)式に(11)，(13)式の関係式を代入する z

$$
S^{\prime}=\sum_{k=1}^{K} 0.25\left(\sigma_{k}^{E_{k}}\right)^{2} /\left(1-\left(\gamma_{k}^{1}\right)^{2}\right) \ldots \ldots \ldots \text { (付 } 17 \text { ) }
$$

となり，乙机は(付15)式右包と等しく，サンプル間隔 が変化してす(11)，(12), (13)，(14)式の関係式で結ば 机ているモデルの理論パワースペクトルの面積法不変 であることが証明された。

(2)式の脳波モデルに関しても，同様に証明するて とができる。 